\title{
To the Question of Formation of Competences for the Safety of Life of Students with Intellectual Disabilities
}

\author{
Natalia Maksimenko \\ Assistant Professor of Special Education and Human Health \\ Central Ukrainian State Pedagogical University named after V. Vynnychenko, \\ Kirovograd, Ukraine
}

\begin{abstract}
The history of society has shown that neglect of security can lead to serious negative consequences and even tragedies, so the achievement of an adequate level of safety is possible only with the high culture and awareness of the entire population of the state. Pupils with intellectual disabilities are of particular concern because they are the most vulnerable.

The urgent issue today is to provide for the needs of each child and to create all the conditions for their full life. Children who have intellectual disabilities need special care.

Currently, the problem of socialization of children with intellectual disabilities is intensifying and their integration into society successfully. The complexity of this problem is determined by the fact that the pupils of both special schools and institutions with inclusive education have quite a variety of profound disorders of psychophysical development.

In such a case, the question arises as to the need for the formation of competencies for safety. This can be done at various levels, including the educational level, by building competencies for life safety in lessons. The formation of students' relevant competences occurs during the entire study. But a special place in this process should belong to the subject "Health Fundamentals". After all, when studying this particular subject, students have the opportunity to develop knowledge, skills and safety skills.

In his work, the author raises the issue of forming competencies for the safety of life of students with intellectual disabilities.

Keywords: competences, pupils with intellectual disabilities, guard, threat, danger.
\end{abstract}

Постановка та обгрунтування актуальності проблеми. Найбільш актуальною проблемою сьогодення є безпека життєдіяльності не лише окремої особистості, а й всього українського суспільства, що визначається дуже помітними нині тенденціями зростання кількості природних і техногенних катастроф. Основною причиною таких зрушень $є$ насамперед людський фактор, оскільки будь-яка діяльність людини у соціумі та у довкіллі здійснюється без відповідного теоретичного обгрунтування і продуманих дій. В такому випадку загострюється питання, що до необхідності формування компетентностей з безпеки життєдіяльності. Це можливо зробити на різних рівнях, зокрема на освітянському, формуючи компетентності з безпеки життєдіяльності на уроках. Формування в учнів відповідних компетентностей відбувається під час усього навчання. Але особливе місце в цьому процесі має належати навчальному предмету 
«Основи здоров'я». Адже при вивчені саме цього навчального предмета учні мають можливість розвивати знання, уміння і навички з безпеки.

Аналіз актуальних досліджень і публікацій. Різним аспектам безпеки життєдіяльності людини присвячено багато теоретичних і практичних доробків таких авторів як: П. Атамчук, В. Мендерецький, О. Панчук, О. Чорна, Ю. Скобло, Н. Герман [5], О. Пуляк, А. Ткачук, С. Желібо, О. Кобилянський, О. Кожемякін, О. Мягченко, та інші, які розглядають проблему у двох напрямках: науковотеоретичному й освітянському.

Педагогічні умови формування здоров'язбережувальної компетентності в учнів загальноосвітніх шкіл аналізують О. Аксьонова, Т. Бабко, Т. Бойченко, А. Карабашева та ін. У системі вищої школи зазначену проблему вирішують Н. Бєлікова, Д. Воронін, О. Дворнікова, О. Дорошенко, Н. Панчук та ін. Сутність поняття «педагогічні умови» досліджують О. Бойцун, Н. Бугаєць, В. Манько, Р. Серьожникова та ін.

Однак проблема формування в учнів 3 інтелектуальними порушеннями компетенції з питань безпеки життєдіяльності розглядається опосередковано. Так, дослідженню проблем життєдіяльності дітей з особливими потребами присвячені праці вітчизняних та зарубіжних науковців: Ю. Василькової, А. Колупаєвої, Т. Ілляшенко, Л. Шипіциної, Е. Даніелс та ін. Такі науковці, як Ю. Василькова, Т. Ілляшенко, А. Колупаєва зазначають, що головною умовою дитячого благополуччя є почуття захищеності батьківською любов’ю та адекватне іiі сприйняття оточуючими.

Заслуговують на увагу праці Л. Калузької, Л. Гураш, О. Лози, які визначили умови організації навчання дітей з особистої безпеки та зміст роботи з формування активної позиції щодо власного життя і здоров’я. Умови і засоби збереження власного життя, допомоги іншим у разі небезпечних ситуацій вивчали Г. Навроцька, Л. Яковенко. Проблема формування у дітей навичок здорового та безпечного способу життя є предметом досліджень Н. Авдєєвої, Н. Бібік, О. Ващенко, Г. Дудчак, С. Кондратюк, І. Калиниченко, Н. Коваль. 
Метою статті $\epsilon$ визначити основні методи формування компетентностей 3 безпеки життєдіяльності учнів початкової школи з порушеннями інтелектуального розвитку.

Виклад основного матеріалу дослідження. Формування компетенцій 3 безпеки життєдіяльності багато в чому залежить від особливостей навчальновиховного процесу закладу освіти та методів, що використовує учитель на уроці. Це створює необхідність удосконалення сучасної освіти та спонукає науковців до обгрунтування та пошуку ефективних методів формування компетентностей 3 безпеки життєдіяльності.

У навчально-виховному процесі, формування знань 3 безпеки життєдіяльності, містить усвідомлення й засвоєння світоглядних основ у сфері безпеки життєдіяльності, відповідних компетентностей та компетенції, формування принципів безпечного існування у соціумомі [10]. Все це має бути реалізовано через систему практичних занять, що спрямовані на засвоєння й усвідомлення знань, умінь і навичок з безпечної життєдіяльності.

Компетентності з безпеки життєдіяльності - це готовність самостійно вирішувати питання власного захисту і захисту оточуючих у процесі певної діяльності, вміння реагувати на небезпеки та знешкоджувати їх, користуватися принципом безпечної життєдіяльності. Суть компетентностей 3 безпеки життєдіяльності проявляється у проведенні профілактичних заходів, застосуванні технологій та методів безпечної життєдіяльності[3].

Науковець Л.Калузька зазначає, що для дитини здоров’я набуває сенсу тільки тоді, коли вона починає розуміти його значення для ефективного виконання тієї чи іншої діяльності у грі або навчанні. У створенні внутрішньої картини здоров’я бере участь вся особистість загалом. Чим складніше психіка, чим різноманітніші мотиви діяльності, тим більшого значення набуває для дитини їі стан здоров’я. У віці 6-7 років дитина не тільки здатна оцінювати своє здоров'я, але і намагається зберігати його, за постійної підтримки дорослих. Коли дитина тільки переступила поріг школи, їй важко звикати до режиму навчання, саме тому потрібна вміла, чуйна і тактовна підтримка вчителя. У своїй педагогічній діяльності педагогу важливо створювати сприятливі умови навчання дитини в школі (відсутність стресових ситуацій, 
адекватність вимог, методик виховання); забезпечувати оптимальну організацію навчального процесу, повноцінний раціонально організований руховий режим. Так, для створення сприятливого мікроклімату доцільно: перевірити освітлення, температурний режим, провірити кімнату, дотримуватись правил гігієни, чистоти в класі, створити затишок, а розсаджуючи дітей за парти, ураховувати: вади здоров'я (зір, слух), зріст, психологічну сумісність. [6]. Упроваджуючи нові прогресивні технології та інтерактивні методи навчання, учителеві слід дотримуватися правила: «Не нашкодь, навчаючи». Для цього під час навчального процесу потрібно стежити за своєчасною зміною статичної напруги під час письма та читання (фізкультхвилинки, вправи для корекції зору, музичні паузи); забезпечувати зміну різних видів навчальної діяльності, використовувати наочність з урахуваннями вимог гігієни; ураховувати позитивні емоції, які полегшують засвоєння матеріалу, що, своєю чергою, зменшує втому, стимулює вищу нервову діяльність, покращує психологічний клімат у класі. Компетенції безпеки життєдіяльності молодших школярів цілеспрямовано формуються на уроках з основ здоров'я [7]. Метою цього предмету визначено формування в учнів здоров'язбережувальних компетенцій на основі засвоєння ними знань про здоров'я та безпеку, практичних навичок здорового способу життя та безпечної поведінки, повсякденної практичної діяльності щодо збереження власного здоров'я та здоров'я інших людей, що сприятиме утвердженню ціннісного ставлення до життя і здоров'я. Науковці доводять, що компетенції $є$ особистісним утворенням, яке проявляється в процесі активних самостійних дій людини. У контексті безпеки життєдіяльності ці компетенції визначають як знання, уміння і навички, за допомогою яких людина може бути максимально готовою до всіх нестандартних ситуацій і явищ навколишнього середовища. Проведення уроків 3 основ здоров'я у початковій школі полягає в тому, що оволодіння комплексом компетенцій зі збереження здоров'я і безпеки життєдіяльності потребує багаторазового вправляння, насамперед у процесі групової взаємодії. Тому необхідна організація практичної, ігрової, індивідуальної та колективної діяльності учнів, що грунтується на суб'єктсуб'єктній взаємодії вчителя з учнями і учнів між собою. Такий підхід (за визначенням ООН) отримав назву «освіта на основі набуття життєвих навичок» і характеризується застосуванням інтерактивних методів 
навчання, що забезпечує ефективне засвоєння учнями навчального матеріалу i відпрацювання ними поведінкових навичок[2].

Виховання дитини з порушеннями інтелектуального розвитку вимагає врахування особливостей їх розвитку та сприймання навколишнього світу, в першу чергу - надання знань щодо їх безпеки. Тут важливого значення набуває коло спілкування (колектив однолітків як референтна група), що впливає на їх соціалізацію[1].

Ключовим моментом модернізації сучасної системи соціального супроводу та освіти є положення про створення умов для розвитку і самореалізації людини. Стратегія модернізації системи супроводу людини з особливими можливостями здоров'я та його освіти ставить перед фахівцями - спеціальними (корекційним) педагогами - нові орієнтири у визначенні корекційно-розвивальних технологій, спрямованих на підвищення можливостей до адаптації, соціалізації дітей, в тому числі і з важкими порушеннями інтелектуального розвитку. Ця стратегія безпосередньо зачіпає i спеціальні (корекційні) установи. Також необхідно відзначити, що сучасна система освіти трансформується, змінюється, визначаються нові освітні стандарти, в основу яких покладено компетентнісний підхід [8].

Використання компетентнісного підходу при навчанні учнів 3 порушеннями інтелектуального розвитку означає поступовий перехід від репродукції знань і навичок до конструювання змісту освіти, застосування різних моніторингів та використання систем контролю якості освіти. При наявності такої сильної практичної складової зміст навчального процесу буде будуватися на основі освоєння навчальних компетенцій[8]. Використання в педагогіці поняття "компетенції", як синонім "компетентності" призводить до того, що розуміння проблеми формування компетенцій стає подвійним. 3 одного боку це може означати уточнення, розширення уявлень про самих компетенціях, а з іншого - розвиток знань і умінь у учнів.

Компетентність - ця міра відповідності знань, умінь і досвіду осіб певного соціально-професійного статусу реальному рівню складності виконуваних ними завдань і розв'язуваних проблем.

Навчальна компетенція - характеристика вимог до навчального, які дозволять стати йому компетентним у навчальній діяльності. 
Дж. Равен, основоположник психологічної теорії компетентності, дає визначення "компетентності як сукупності компетенцій", підкреслюючи ї множинність. У теоретичних дослідженнях вітчизняних вчених (В.М. Галямін, І.А. Зимової, Н.А. Селезньова, В.В. Серікова, А.А. Хутірського і ін.) Відзначається, що компетентність набувається і формується в процесі життєдіяльності, і являє собою особистісну характеристику, що розглядається в двох аспектах: об'єктивному і суб'єктивному. У більшості випадків, об'єктивний аспект, який включає фундаментальні знання і вміння, реалізується в діяльності, в тому числі і трудовий. Суб'єктивний аспект характеризується позитивною мотивацією суб'єкта до даної діяльності, ціннісносмисловими уявленнями про зміст і результат. У спеціальних психолого-педагогічних дослідженнях узагальнено наукові дані, що відображають зміст і компоненти компетентності (когнітивний, мотиваційний, поведінковий, рефлексивно-оцінний), а також дано визначення базових навчальних компетенцій, таких як: навчальнопізнавальні; ціннісно-смислові; інформаційні; комунікативні; соціально-трудові. Європейський варіант ключових компетенцій включає вміння: вивчати; шукати; думати; співпрацювати; братися за справу; адаптуватися [8]. Безпека як об'єктивна реальність проявляється у відсутності або мінімальному рівні ризику виникнення збитків інтересам людини (здоров'ю, матеріальному благополуччю і т.д.) в звичайних умовах і при взаємодії з шкідливими і небезпечними чинниками життєдіяльності.

У той же час безпека життєдіяльності - це галузь наукових знань, що охоплюють теорію і практику захисту людини від небезпечних і шкідливих чинників у всіх сферах людської діяльності і середовищі проживання. [9].

Особлива небезпека підстерігає учнів початкової школи 3 порушеннями інтелектуального розвитку. Завдання дорослих полягає не тільки в тому, щоб захистити і оберігати дитину, але і в тому, щоб підготувати іiі до зустрічі з різними складними, а часом небезпечними життєвими ситуаціями.

Необхідно підкреслити такі правила поведінки, які учні зобов'язані виконувати неухильно, так як від цього залежить їхнє здоров'я і безпека. Ці правила необхідно грунтовно роз'яснювати учням, а потім спостерігати за їх виконанням. Крім цього, учні можуть опинитися в несподіваній ситуації на вулиці і вдома, тому основним завданням $\epsilon$ стимулювання розвитку в учнів самостійності і відповідальності, так як все без 
винятку, чого навчають учнів, вони повинні вміти застосовувати в реальному житті, на практиці. [5].

На нашу думку, для більш кращого засвоєння інформації про безпеку/небезпеку потрібно використовувати 3Д технології. Таким чином учні не лише побачать певну ситуації, а й ще стануть повноцінними учасниками. Так, наприклад, при моделюванні ситуації правил дорожнього руху, можна трансформувати за допомогою ЗД технологій рух машин і запропонувати учням перейти дорогу. Якщо, хтось з учнів не правильно вчинить, то шкоди здоров'ю імітована машина не принесе, а учень набуду життєвого досвіду.

Правила поведінки та заходи безпеки головним чином взаємопов'язані 3 умовами проживання людини, будь то сучасний місто або сільська місцевість, звична домашня обстановка - кожна середа диктує абсолютно різні способи поведінки і запобіжні заходи.

Висновки. Розуміючи, що учні з порушеннями інтелектуального розвитку ніколи не стануть настільки самостійними, щоб обходитися без допомоги і підтримки дорослої людини. Але кінцевою метою нашої роботи по формуванню компетенції у школярів 3 обмеженими можливостями здоров'я ми бачимо в тому, щоб навчити їх бути по можливості комунікабельними, розумно активними, які вміють звертатися по допомогу і приймати іï, бути культурними в поведінці і вести здоровий спосіб життя , бути корисними хоча $б$ в рамках своєї родини. В кінцевому підсумку це $\epsilon$ найважливішою передумовою для подальшої соціальної адаптації, яка є найважливішим завданням навчання і виховання учнів початкової школи в спеціальному (коррекционном) закладі, за допомогою можливої корекції і компенсації первинного дефекту i вторинних порушень

\section{References}

1. Atamanchuk, P.S., Menderets'kyy, V.V., Panchuk, O.P., Chorna, O.G. (2011) Bezpeka zhyttyediyal'nosti [Life Safety] navch. posib. Kyyiv. 276.

2. Tkachuk, A.I., Pulyak, O.V. (2017) Bezpeka zhyttyediyal'nosti ta osnovy okhorony pratsi. Kurs lektsiy [Safety of life and the basis of occupational safety. Course of lectures] navch. posib. Kropyvnyts'kyy. 184. 
3. Skoblo, YU.S., Sokolovs'ka, T.B., Mazorenko, D.I., Tishchenko, L.M., Troyanov, M.M. (2003) Bezpeka zhyttyediyal'nosti [Life Safety] navch. posib. Kyyiv. 424.

4. Zaporozhets', O.I., Zaplatyns'kyy, V.M., Khalmuradov, B.D., Prymenko, V.I., Mykhaylyuk, V.O., Kanitsula, T.YA. (2013) Bezpeka zhyttyediyal'nosti [Life Safety] pidruchnyk. Kyyiv. 448.

5. Herman, N.V. (2000) Bezpeka zhyttyediyal'nosti lyudyny $\mathrm{v}$ pedahohichniy spadshchyni ukrayins'kykh prosvityteliv (kintsya XIX - pochatku XX stolittya) [The safety of human life in the pedagogical heritage of Ukrainian educators (the end of the nineteenth and early twentieth centuries)] avtoref. dys. Kyyiv. 17.

6. Kobylyans'kyy, O.V. (2013) Kompetentnisnyy pidkhid do vyvchennya dystsyplin tsyklu bezpeky zhyttyediyal'nosti u vyshchykh navchal'nykh zakladakh [Competent approach to the study of life cycle safety disciplines in higher education institutions] Naukovyy visnyk Skhidnoyevropeys'koho natsional'noho universytetu imeni Lesi Ukrayinky. № 7. 42-47.

7. Kozhemyakin, O.S. (2015) Optymizatsiya metodolohiyi formuvannya kompetentnosti $\mathrm{z}$ bezpeky zhyttyediyal'nosti [Optimization of the methodology of forming competence for life safety] Nauka i osvita. № 5. 45-52

8. M.V.Luzyk. Suchasni problemy formuvannya zhyznenatsional'nykh dosyahnen' ditey z obmezhenymy mozhlyvostyamy zdorov'ya zdorov'ya .// Korektsiyna ta sotsial'na pedahohika ta psykholohiya. - 2012.- №4 s.338-345

9. Polishchuk, O.V., Repins'kyy, S.V., Slabkyy, A.V. (2016) Formuvannya kompetentsiy $\mathrm{z}$ bezpeky zhyttyediyal'nosti $\mathrm{v}$ studentiv vyshchykh navchal'nykh zakladiv [Formation of competences for the safety of life in students of higher educational institutions] Pedahohika bezpeky. № 1. 72-80

10. Sadovyy, M.I. (2017) Naukovo-metodychni pryntsypy eksperymental'noyi ta doslidnoyi diyal'nosti maybutnikh uchyteliv tekhnolohiy [Scientific and methodical principles of experimental and research activity of future technology teachers] Naukovi zapysky. Seriya: Problemy metodyky fizyko-matematychnoyi i tekhnolohichnoyi osvity. Vyp. 11, CH. 3. 147151. 


\section{Translation of the Title, Name and Abstract to Author's Language}

Анотація

\section{УДК 376.42}

\section{Максименко Н.В. До питання формування компетентностей 3 безпеки}

\section{життедіяльності учнів 3 порушеннями інтелекту.}

У статті проаналізовано стан розробленості проблеми, що досліджувалась у загальній та спеціальній психолого-педагогічній літературі; викладено результати аналізу концептуальних підходів до проблема формування компетентностей 3 питань безпеки життєдіяльності, означено сучасний стан проблеми, зокрема проблема формування компетентностей з питань безпеки життєдіяльності в учнів 3 порушеннями інтелектуального розвитку.

\section{Лimepamypa:}

1. Атаманчук П.С. Безпека життєдіяльності: навч. посіб. / Атаманчук П.С., Мендерецький В.В., Панчук О.П. Чорна О.Г. - К.: Центр учбової літератури, 2011. - 276 c.

2. Ткачук А.І. Безпека життєдіяльності та основи охорони праці. Курс лекцій: навч. посіб. для студ. вищ. пед. навч. закл. всіх спец. за ОКР «бакалавр» / А.І. Ткачук, О.В. Пуляк. - [перевид. доп. та перероб.]. - Кропивницький: ПП «ЦОП «Авангард», 2017. $184 \mathrm{c}$.

3. Безпека життєдіяльності: навч. посіб. для вищ. навч. закл. III-IV рівнів акредитації / Ю.С. Скобло, Т.Б. Соколовська, Д.І. Мазоренко, Л.М. Тіщенко, М.М. Троянов. - К.: Кондор, 2003. - 424 с.

4. Безпека життєдіяльності: підруч. / O.I. Запорожець, В.М. Заплатинський, Б.Д. Халмурадов, В.І. Применко, В.О. Михайлюк, Т.Я. Каніцула. - К.: Центр учбової літератури, 2013. - 448 с.

5. Герман Н.В. Безпека життєдіяльності людини в педагогічній спадщині українських просвітителів (кінця XIX - початку XX століття): автореф. дис. на здобуття наукового ступеня канд. пед. наук: спец. 13.00.01 «Загальна педагогіка та історія педагогіки» / Н.В. Герман. - К., 2000. - 17 с.

6. Кобилянський О. Компетентнісний підхід до вивчення дисциплін циклу безпеки життєдіяльності у вищих навчальних закладах / О. Кобилянський // Науковий вісник 
Східноєвропейського національного університету імені Лесі Українки. - 2013. - № 7. C. $42-47$.

7. Кожем'якін О.С. Оптимізація методології формування компетентності з безпеки життєдіяльності / О.С. Кожем’якін // Наука і освіта. - 2015. - № 5. - С. 45- 52. - Режим доступу: http://nbuv.gov.ua/UJRN/NiO_2015_5_10. 10. Мягченко О.П. Безпека життєдіяльності людини та суспільства: навч. пос. / Мягченко О.П. - К.: Центр учбової літератури, 2010. - 384 с.

8. М.В.Лузик. Современные проблемы формирования жизненноважных компетенцийу детей с ограниченными возможностями здоров'я.// Корекційна та соціальна педагогіка і психологія. - 2012.- №4 с.338-345

9. Поліщук О.В. Формування компетенцій з безпеки життєдіяльності в студентів вищих навчальних закладів / О.В. Поліщук, С.В. Репінський, А.В. Слабкий // Педагогіка безпеки. - 2016. - № 1. - С. 72-80.

10. Садовий M.I. Науково-методичні принципи експериментальної та дослідної діяльності майбутніх учителів технологій / M.І. Садовий // Наукові записки. Серія: Проблеми методики фізико-математичної і технологічної освіти; відп. за випуск: М.I. Садовий. / КДПУ ім. В. Винниченка. - 2017. - Вип. 11, Ч. 3. - С. 147-151. 